\title{
A Literary Interpretation of Blood Symbolism in Ifá Divination Poetry
}

\author{
Oluwabunmi Tope Bernard \\ Obafemi Awolowo University, Ile-Ife, Nigeria. \\ bunmibernard@oauife.edu.ng
}

\begin{abstract}
This study undertakes a literary analysis of blood as a symbol as contained in the Ifá divination poetry among the Yorùbá of Southwestern Nigeria, which the researcher has collected through personal observations, consultations, and interviews with Ifá priests. Using Ricoeur's hermeneutics theory of interpretation, the findings show that the selected Ifá divination poems present the symbolic interpretations of blood in Ifá corpus as it is entrenched in the Yorùbá psychology, sexuality, religiosity, worldview, identity and kinship. The paper presents that blood is multifaceted among the Yorùbá.

\section{Introduction}

The online Encyclopedia Britannica defines blood as "fluid that transports oxygen and nutrients to the cells and carries away carbon dioxide and other waste products." This means that unimpeded blood flow is central to having a healthy life and a well-functioning body. Nabofa (1985) emphasizes this point in his work on blood symbolism in African religion, observing that:

In most African concepts of being or existence, it is held that when the vital life force ceases to vibrate in man or animal the functioning of the heart, and consequently, the circulation of the blood will come to a standstill and the life of such a creature will terminate (390).

In his extensive and insightful discussion of the functions and sacred significance of blood in African religion and culture, Nabofa shows the variety of ritual contexts in which blood features prominently. In addition to using it to administer oath, Africans also dispense blood to avenge wrongdoing and as nutrients for witches, wizards and sorcerers, and for healing and renewal
\end{abstract}


of life. Yet, while Nabofa's study helps show the explanatory power of African religious beliefs for understanding the symbolic value of blood, the study is lacking in critical analytical rigor. It fails to examine the rich hermeneutical potential of these traditions as a framework for interpreting and interrogating the diverse ritual contexts considered necessary for using blood. The present study seeks to fill this lacuna by engaging in a critical exegetical study of relevant Ifá divination poetry and of the oral data obtained from Ifá priests.

Blood is common to all living things, animate and inanimate alike. It also cuts across every creed and race. To cultures like the Hebrews, Greeks and Arabs, blood is more than just body fluid, it is also symbolic because of its association with ritual unpleasantness, death and oath sacrifice (McCarthy 1973:205-207). The Yorùbá also handle blood with awe and reverence because of their belief that it is sacred and mysterious. However, to understand the basis and rationale for this belief, it is important to examine the Yorùbá epistemological system found in Ifá.

Studies in symbol systems are always fraught. This is because of what one might call the twin interpretive dangers of over-inclusiveness and under-inclusiveness, the former ascribing more meaning than originally intended or warranted by the object's local provenance, and the latter committing an obverse error. As, Leslie (1949) opines:

A symbol may be defined as a thing of value or meaning which is bestowed upon it by those who use it. I say 'thing' because a symbol may have any kind of physical form: it may have the form of a material object, a color, a sound, an odor, a motion of an object, a taste (25).

As a symbolic object, blood is not immune to these divergent context-variant interpretations. An important task of this essay is to unfold the variety of meanings the Yorùba have come to associate with blood, which include life, fertility, covenant, danger, sacrifice, neutralizer, identity and kinship.

\section{Yorùbá Culture, Ifá Divination Poetry and Symbolism}

Yorùbá culture, like other cultures, is complex. It consists of many elements that are essential to its extant nature and shape across the broad gamut of Yorùbá social space. (Odejobi 2013:221). One of such elements is the Yorùbá belief system, comprising various divinities, among which is Ifá, also known as Ờrúnmilà. When in need of clarity to issues in any aspects of life, the devotees will visit the Ifá priest who, as the spokesperson for the divinity, will perform Ifá divination for the inquiring devotee. One of the ways through which Ifá speaks and gives answer to questions is through the ẹsẹ-Ifá (Ifá divination 
poetry) and the core essence of Ifá divination poetry among the Yorùbá is its symbolism. As an amalgam of metaphysical and epistemological principle, "Ifa represents a body of deep knowledge that deals with the past, present and future all at once" (Olupona 2011:177). To assure its efficacy and credibility, Ifá relies on toolkits of symbols to convey insights and instructions to inquiring devotees. Symbolism, according Morton (1979), is:

A system of signs and as such - like language properly speaking - is a matter for semiology. But while language has its own signals which are only defined by their reciprocal articulation and their relation to linguistic meaning, symbolism uses as signals elements, acts or utterances that exist, and are also interpreted, independent of it (5).

So understood symbols are very much like words because they speak to and could be heard by those who use them. Symbols are embedded in culture because they are among the things that humans construct and use to facilitate and structure social interactions. This may be why Charon (1998) suggests that "symbols are social objects used to represent (or 'stand in for', 'take the place') whatever people agree they shall represent" (47). Because "symbols give rise to thought" (Ricoeur 1974:288), the Yorùbá, like any other people, do not treat symbols with cognitive and affective indifference; rather, every encounter with empirical instantiations of symbols always triggers an existential quest to understand what they mean. This search for meaning is normatively bounded by the two worlds in the Yorùbá cosmology: the visible and the invisible worlds, which are functionally and substantively complementary to and interdependent with each other (Taiwo 2016:100). As people understand them, the visible world is a mimetic reiteration of the invisible one; the affairs and experiences in one realm are believed to have reciprocal reverberations in the other.

\section{Interpretation of Blood in Ifá Divination Poems}

Ifá has significant epistemic references for understanding the nature of the Yorùbá belief system. It is simultaneously interpreted as a divinity, an indigenous knowledge, a human and divination objects. To the Yorùbá, Ifá is a store-house of the people's worldview, so, whatever is found in Ifá is practiced in Yorùbá culture. The Yorùbá glean their understanding of blood's symbolic significance from its representations in Ifá. 


\section{Blood Symbolism in Yorùbá Marriage}

As earlier noted, the Yorùbá culture is a complex ensemble of beliefs and norms that shape people's orientations and guide their actions. For instance, the structure and value dynamics of Yorùbá family reflect the background cultural template, such that they do not consider a marriage fully binding until it produces children or recognize a woman as a mother until she gives birth to living children. Children are considered to be the profit of marriage and even life itself. This informs a Yorùbá saying: ọmọ lèrè igbéyàwò, ọmọ lèrè ayé (children are the profit of marriage and life). Hence, a life lived by one without children to replace one is considered a wasted life. A Yorùbá adage that says bí iná bá kú, a fi eérú bojú; bi ọgẹdẹ bá kú, a fí ọmo rẹ rọ́pò; bí babaláwo bá kú, ọmọ wọn ní jogún ẹbu (when fire extinguishes, it is replaced by ashes; when a plantain tree withers, it is replaced by its suckers; when an Ifá priest dies, his divination paraphernalia is bequeathed to his children). The preceding adage confirms the Yorùbá belief that blood-lines and human race are preserved through children; therefore, the Yorùbá people do go to great lengths to become parents. The indigenous Yorùbá society is mostly heterosexual that is why it is considered the norm for a man to marry a girl. It is however important to not just marry but marry a virgin girl, deflower her during sexual intercourse and which they hope will result into pregnancy. During sexual intercourse between newly-weds, sighting of blood is important because it indicates that the virginity of the bride was intact. Ajibade (2009) explains the breaking of the hymen on the wedding night as an important rite and a pointer to the fertility of the bride. As he says:

Premarital women's virginity is held in high esteem among the Yorùbá. In traditional Yorùbá society, any woman discovered not to be a virgin on the day of marriage is regarded as loose, corrupt, wayward, useless and a deviant. If such a woman had problems of infertility, it is sometimes considered the consequence of past waywardness (139).

This underscores a common assumption about blood secretion as evidence of womanhood when sighted after the post-wedding first coitus, which also signifies the woman's readiness to become a mother. Anything short of that will spell the doom of childlessness for the marriage.

One of the duties of mothers in traditional Yorùbá society is teaching their daughters the values that are required in navigating the society such as self-keeping and family-keeping. Part of the training vital to self-keeping is what to do when a girl-child sees her first period and what to do during and after the period. In some Yorùbá towns, when a girl reaches puberty and sees 
her monthly period for the first time, her mother kills a cockerel to celebrate its arrival, a rite that has a deep libatory significance. First, the arrival of the girl's monthly blood flow confirms her physiological fitness for motherhood status, and the shedding of the cockerel's blood imitates and signifies the girl's shedding of her first monthly blood. In the Yorùbá worldview, blood goes hand in hand with bearing children. Consequently, a newborn baby is referred to as èjẹ ọrun (heaven's blood). The choice of the language of èjẹ (blood) rather than ara (body) to denote the baby's identity is because the blood's fluidity resembles the fragility of the baby at birth, which makes it easy and flexible to pass through the birth canal. In addition, the only cover on the baby's body upon exit from the womb is the mother's blood, further reinforcing the sense of mystery surrounding childbirth and the mystique of blood inherent in this event. An extract from Odù İkároșùn of the Ifá divination poem agrees that there is a connection between a newborn baby and blood:

İkároșùn hòó, awo Ilé,

Ló difá fún Ilé.

Ẹrọ̣ șọsọ̣ awo ẹjẹ,

Ló dífá fún ẹjẹe,

Tí șalábàárin ọmo tuntun.

Ėjẹ ló lọ dífá pé òun fẹ jẹ ẹni pàtàki láyé,

Bí wọn ò bá rí òun,

Enikéni kò ní lé bímọ.

Wọnn ní kí ẹjẹ ó rúbọ,

Ó sì rúbọ.

Láije pé obinrin rí èjè,

Omọ tuntun kò lè wáyé.

Kè è pẹ, kè è jìnnà,

E báni ní jẹbútú ọmọ.

İkároșùn, the priest of Ilé,

Was the one that performed divination for Ilé.

The-one-that-drips, the priest of blood,

Was the one that performed divination for blood,

That accompanies newborn baby.

Blood performed divination so that it can become eminent,

If it is not seen,

No one can give birth to children.

1 The data was collected from the oral interview conducted with Awo Oladiran Mathew at Ogbomoso in Oyo State, Nigeria on 10-29-2017. 
Blood was instructed to prepare sacrifice,

It did.

If a woman did not see blood,

No newborn babies can be given birth to.

It was not long,

That people started jubilating at the arrival of a newborn. ${ }^{2}$

One of the signs of pregnancy is the absence of the flow of a woman's monthly period. When the egg that leaves the ovaries is not fertilized by sperm, it is shed with the lining of the uterus as monthly period. On the other hand, when the egg is met by sperm, no blood is seen. Therefore, the excerpt from the Ifá verse above is about the importance of blood in aiding the arrival of children. If blood is not seen, there cannot be any hope of pregnancy, then the blood ceases when the egg is fertilized and appears again when the child is ready to be born. Also in line 3 of the Ifá verse, the name of the priest that performed the divination for blood symbolizes the liquid nature of blood. The name of the priest is Ẹrọ̀ șọ̀ọ̣ (The-one-that-drips), which means it is important for blood to constantly be in liquid form to give life. If blood that is still inside the body starts to coagulate, it will, in due course, lead to death.

The Yorùbá believe that another kind of blood can also flow from a woman's womb. Such blood is called èjẹ dúdú (the bad or black blood). When this blood flows from a woman's womb, it can cause her to be childless. Apter (2013) validates this point:

the cultural semantics of the blood of mothers is at once concrete and abstract, a distilled essence of womanhood with positive and negative values, as it were; positive in the capacity to mix with male sperm and create new life; negative in the menses, understood as "bad blood" ejected by the womb because it cannot create new life (73).

In essence, Apter opines that if a woman keeps producing bad or black blood monthly, she may not have children because only a good and clean blood can create new life. An extract from Odù Òfúnsẹẹ expresses the importance of having good blood for a woman:

Òfúsẹẹ, İyàsùn-un,

Afúnșo tán, ișé ò gbẹ,

A difá fun Àrò,

Tín lọ ile bàbámọle tín lọ rè é bí onírúurú lọmọ.

2 All Ifá divination poetry English translations were done by the author. 
Òjò dúdú dúdú dúdú ní tí ń rọ lápà.

Alápáníyàwé,

Ebọ ni wọnn ní kó șe,

Kí omi pupa ò lè débẹ. ${ }^{3}$

Òfúsẹẹe, İyàsùn-un,

After wringling a piece of cloth, it does not dry,

Ifá divination was performed for Àrò,

That went to bàbámọ lẹ's house to give birth to all sorts of children.

There was pitch-black rain from the uterus.

Alápáníyàwé,

She was told to make sacrifice,

So that red water might replace the pitch-black rain.

The Ifá divination poem above spoke about Alápáníyàwé, who could not have children of her own because she was discharging "pitch-black rain" monthly. She was told to make sacrifice to the divinities so that her pitchblack rain would be changed to "red water". The "pitch-black rain" in the extract represents the bad blood that causes infertility whereas, the "red water" symbolizes fertility. When Alápáníyàwé made the sacrifice as she was instructed, she started discharging the "red water" that then caused her to have children. Bad blood-flow from a woman's womb is not only feared by women, it is also a cause for concern to men as well. Men dread the bad blood that is ejected from women's wombs precisely because it is believed to possess nullifying capabilities that can "neutralize their most powerful medicines through physical contact" (Drewal and Drewal 1983:79). The neutralizing effect of bad blood is potent on both pregnancy and powerful medicines.

\section{Symbolic Interpretation of the Relationship between Yorùbá Divinities and Blood}

As earlier noted, another important aspect of the Yorùbá's complex culture is the belief in many divinities which underlie the proper function of the society. As Adeniyi notes, (2015:175), "it is an indubitable fact that the Yorùbá are endowed with diversity of divinities." These divinities are the fulcrums that turn the wheels of the Yorùbá society as well as the threads that hold the society in place. Every divinity has devotees. The custodians ${ }^{4}$ of each divinity

3 The data was collected from the oral interview conducted with Awo Oladiran Mathew at Ogbomoso in Oyo State, Nigeria on 10-29-2017.

4 Custodians are persons who guard and protect a set of ideas or beliefs. In African Indigenous Religion, custodians of divinities are keepers of indigenous knowledge systems pertaining to a particular divinity (Mokgobi 2014:25). They are also spokespersons 
take great care to ensure a loyal devotion of other worshippers of the divinity and adherence to the liturgical structure of the worship, which involves libation. Libation can take any of three forms; it can be water, liquor or blood libation but the most significant is the blood libation. Akindipe (2016) says:

Libation with blood applies to all the deities... the blood libation mostly involves sprinkling an animal's blood - birds, goats, cows and the like - on the deity. This form of libation happens only when it is crucial (198).

Blood libation is considered crucial because a life must have been taken before there can be blood. So, any sacrifice to the divinities that involves the shedding of blood is considered to be of high significance because a life is being used as a replacement for another. Ifá, also known as Ờrúnmilà, is one of the major divinities that descended from heaven to Ilé-Ifẹ by means of an iron chain; he holds a premier position among the Yorùbá divinities (Abimbola 1975:2). Therefore, when it is necessary to appease Ifá or to impel him to grant certain wishes, blood libation is the tool used by devotees to achieve the feats. Odù Ộsárosùn, an Ifá verse, corroborates this claim:

Wọ́n rú rú rú agara ẹbọ dá wọn.

A dífá fún Olóngere iṣàdè-àbà tíi șọmọ Amilú ago.

Ó yàgàn,

Ó ya páta kò rộmọ bí.

Ó rọmọ léyin adirẹ, ó bú sệkún.

Ó ní bẹe Ò Oișà ló șerú èyí fẹyẹ oko.

Wọn ní kó rúbo ewúré mẹta,

Ewúrẹ kan ló rú,

İgbá tí ó bí $i$,

Ó bí Ikútánńlé fún wọn ní ilú Ọ̦̣n mẹri.

Ó kurò níbẹ,

Ó bí Àràotí fún wọn lóde İjẹșà.

Ó tún kúrò níbẹ,

Ó bí Roronrárà fún wọn ní Ọyọ́-Ộrọ-Mọ̀kọ.

Ikútánńlé ń jiyan nílé baba rẹ.

for these divinities. Through the custodians, the presence of divinities may be established (Akindipe 2016:308-309). There are several ways by which a person may become a divinity's custodian. A person may become a divinity's custodian by the choosing of the divinity through divination or by circumstances surrounding conception and birth of the person, through training under a master-custodian, by succession whereby the custodian succeeds the former custodian (daughter succeeding mother or son succeeding father) or by self-choosing. 
Àràotín jẹkà lẹẹè baba rẹ.

A gúnyán lẹ́bẹ, a gbé e fún Roronrárà,

Ko jẹ, ẹkún nín sun.

A rokà lẹbè, a gbé e fun Roronrárà,

Ko jẹ, ẹkún ní nun.

Ni jé kíni Lẹdú ó jẹ?

Èjẹ ni Roronrárà ó jẹ.

Bẹdùu ba jẹ èjẹ,

A máa lájé, láya, bimọ, níre gbogbo.

Ėjẹ ni Roronrárà ó jẹ.

E.jẹ. ${ }^{5}$

They made many sacrifices and became frustrated,

Ifá divination was performed for Olóngere ìsàdè-àbà the child of Amìlú ago.

She was barren,

She was unproductive, she could not have a child.

She saw a hen with its chicks and burst into tears.

She lamented and said it is the gods that did this for a bird of the forest.

She was asked to sacrifice three goats,

She sacrificed one,

When it was time for her to give birth,

She gave birth to Ikútánńlé for them in the town of Ọ̣sun mẹri.

She left there,

She gave birth to Àràotí for them in İjẹșà.

She left there again,

She gave birth to Roronrárà for them in Òyọ́-Ọrộ-Mộkọ.

Ikútánńlé is eating pounded yam in his father's house.

Àràotí is eating yam flour in his father's compound.

We made smooth pounded yam for Roronrárà,

He did not eat, he was weeping.

We made a soft yam flour for Roronrárà,

He did not eat, he was weeping.

What will Lẹ̀dú eat?

Roronrárà will eat blood.

When È dú eats blood,

We are blessed with riches, wives, children and all sorts of good fortune.

Roronrárà will eat blood.

5 The data was collected from the oral interview conducted with Awo Fakayode Fayemi at Ibadan in Oyo State, Nigeria on 03-26-2018 
Blood.

In the excerpt from Ifá divination poem above, both Roronrárà and Ẹdú are appellations of Ộnumilà. From the excerpt, one can infer that blood is very important to Ộrúnmilà because he would not eat any other food except blood. This means that when blood libation is performed for Ộrúnmì̀à, his devotees are blessed with all the good things that their hearts desire because the life force (blood) offerings elevate our prayers to the divinities for our benefit and rearrange forces in the universe to work in our favor when we work hard at it.

\section{Economic Interpretation of Blood Symbolism}

The herbalists are the ones who specialize in incisions making, ears piercing, tribal marks cutting and circumcisions. Oguntola-Laguda (2015) attests to this that, "incisions (gbẹreé) among the Yorùbá traditional healers (herbalists) are common. The incisions could be made with razor blades, knives, axes, cutlasses, and needles, among other objects" (116). It is therefore believed that a visit of a traditional healer who specializes in the art making incisions/body artist to a town must involve the shedding of blood, which in this particular context, symbolizes ailment that is being purged from the body. As confirmed in Odù Òtúrúpọ́nșokùn, an Ifá verse:

Aróṣogbobi.

Abidí-abejátí.

A difá fún Olóòlà,

Omọ așámọ lógbé șere șere gbowó.

Olóòlà kí wọlú àifọwọ bèjẹ.

Òwò ẹjẹ làwa ń șeé là nílé wa. ${ }^{6}$

Arósọgbobì.

The-one-that-uses-blade-to-pierce-ears.

Ifá divination was performed for Olóòlà,

The child of the-one-that-incised-a-child-gently-to-get-paid.

Olóòlà does not enter a town without touching blood.

We are in the business of profiting from blood in our family.

As grim as the shedding of blood by an Olóòlà (body artists (Drewal and Mason 1997)/the creative professionals involved in the art of marking the

6 The data was collected from the oral interview conducted with Awo Oladiran Mathew at Ogbomoso in Oyo State, Nigeria on 10-29-2017. 
body (Faleye 2008)) may seem, it is a cultural phenomenon among the Yorùbá. They believe that illnesses such as infertility, born-to-die, migraine, bad blood and other kinds of infirmities can be cured through this means. This is so because the Olóòlà does not only just cut the sick person, he also applies some herbs into the wound that presumably go straight into the bloodstream and commence healing. Hence the common saying that "the life of a man is in his bloodstream" (Makinde 1988:90). So, when the herbs go into the bloodstream through the cuts, it heals the sick. In the process of creating health for the sick, shedding of blood also creates wealth for the Olóòlà which in turn contributes to the economic development of the society.

The ancient Yorùbá believed in predestination and so, will not embark on anything without first consulting Ifá, the divinity that eye witnessed all humans' choice of fate. That is why he is called ẹlẹrií-ìín (the-one-who-witnessed-the-choosing-of-fate). “To an average Yorùbá, success or failure, long life or early death, wealth or poverty, are aspects of humans' experience which are predestined" (Abimbola 1975:32). So, they go to Ifá to inquire into the fate (esè-n-táyé) of a child born to them. If the child has chosen a bad fate that will end in poverty, elders in the family will perform sacrifice on behalf of the child as advised by Ifá priest in the hope that Ifá will make better the fate of the child so that when he is old enough and works hard, through the hard work and patience, he will come into money. However, in the traditional Yorùbá society, "blood money" tales are also very common, and what counts as blood money can take different forms. When youths are living in the affluence that is above their parents' means, it is believed that the money they have is blood money because it must have been gotten through unsavory means that involved murdering somebody. In which case, blood must have been shed. The Yorùbá dread money ritual because it involves shedding of blood. They call it owó gbígbóná (hot money) or owó ẹjẹ (blood money) because the blood of the innocent is shed in the money-making ritual process. Apter (2013) writes:

The purest expression of illicit wealth is found in Yoruba idioms of money-making magic, which converts the blood of kidnapped children into brand-new naira bills. Such "soaked" or "hot" money is typically unproductive and infertile: gained without labor, it is spent without gain (79-80).

Most significantly, the Yorùbá believe it is possible to identify people who are involved in blood money, scapegoating people who suddenly come into unexplainable wealth, spend lavishly and die suddenly at a young age to justify such belief. The thrust of belief is captured in Odù Ogbèalárá, where Ifá says: 
Ifá so pé kí o má fipá wá owó,

Bẹẹ ni kò gbọdọ fipá jayé,

Kó má ba à kú ikú àitọjọ́.

Afipájayé kii pẹ láyé.

Ėèyàn tí bá ń șe gìigirì,

Bo bá șolórí ogun, kò nií dọla.

A difá fún Òrúnmilà,

Lọ́jọ tín lọ bá àwọn ọmọ Eni,

Gba ogbó atọ lộọ̣ Olódùmarè.

Olódùmarè ní òogùn ogbó kan ò sí,

Sùúrù ni oògùn ogbó.

Oògùn atọ kan ò sí,

İwà pệlẹ loògùn atộ.7

Ifá says do not seek money at any cost,

You also must not strive to enjoy the pleasures of life at any cost,

So that you will not die prematurely.

He-who-attempts-to-enjoy-the-pleasures-of-life-at-all-cost does not live long.

A person who is always in a hurry to do things,

If he is made a leader of war, he will not last till the next day.

Ifá divination was performed for Ộrúnmilà,

When he journeyed on behalf of the offspring of Eni,

To received longevity from Olódùmarè.

Olódùmarè says there is no medicine for the acquisition of longevity,

Patience is the potent medicine of longevity.

There is no medicine for long life,

Meekness is the medicine for long life.

The Ifá divination poem above emphasizes the importance of patience and meekness in an effort to accumulate wealth and enjoy the pleasures of life lastingly. This is because any wealth that is ill-gotten is bound to lead to a short life. In the excerpt, blood money is not stated directly in the poem but it is implied. Fipá wa owó (Seek money at all cost) and fipá jayé (strive to enjoy the pleasures of life at any cost) are actions that often times involve shedding of people's blood by either forcefully taking their belongings or forcefully taking their lives, hence, what is referred to as blood money. Growing up in a Yorùbá society, anyone who was suspected to be involved in blood money would be

7 The data was collected from the oral interview conducted with Iyalawo Ojo Ifabukola at Ile-Ife in Osun State, Nigeria on 03-30-2017. 
ostracized because people knew that lives have been lost for such a person to come into the wealth he had. In fact, the Yorùbá dread blood money so much that they avoid transacting business with anyone suspected to be involved in ritual killing to enrich himself. The reason why they do so is that they believe that the blood that was shed to acquire the wealth will corrupt the "good money" the receiver has, as well as disturb relentlessly anyone that partakes of such money. There were stories of the spirits of those killed in blood money ritual crying for vengeance and haunting occupants of the houses that were built with the money. Similarly, there were tales of things such as clothes, household items and so on that were purchased with blood money crying for blood in the middle of the night. On the sudden demise of the culprit, which is usually at a young age or not long after the blood money ritual was done, everything bought with the blood money perishes, so that no one continues to enjoy the wealth after his or her departure. Even, the family of such a person would be stigmatized in the community. In the same vein, hard work is celebrated among the Yorùbá to discourage indolence especially among youths. A person who has come into money through hard work brings honor to himself and his family. He is respected and honored with chieftaincy titles in his town and other towns who wish to be associated with or who have benefited from his success ${ }^{8}$. However, kings in ancient Yorùbá towns were careful not to make anyone suspected to be involved in "blood money" a chief, in order not to corrupt the good soil of the community and to guarantee continuous peace of mind for people living in such community.

\section{Interpretation of Blood Symbolism in the Yorùbá Indigenous Political System}

The smooth running of a society is largely a function of the synergy of its leaders. Thus, the Yorùbá axiom that says igi kan kì í dá igbó șe (a tree does not make a forest). The indigenous political structure in the Yorùbá society is like a pyramid with the king at the very top of it. In ancient times, the king had absolute power because he is considered to be the second-in-command to the divinities, aláṣe èkejì òrișà. He is sometimes even more dreaded than the divinities because he has physical powers of life and death over his subjects. The king's power over the life of his subjects in the visible world is well articulated in this Yorùbá adage that bí Ifá bá fọ ire, bi ọba ò bá fọ ire ńkộ? (What if Ifá foresees goodness and the king says otherwise?). What that infers is that even though divinities are revered and their words carry a lot of

8 To read more about the Yorùbá's perception of hard work, see: Bernard, O.T. (2018). "The Construction of Poverty in Selected Yorùbá Written Poetry" Poverty and the Humanities. Faculty of Arts, Obafemi Awolowo University. Ile-Ife. Nigeria. Pp 189-204. 
weight in the Yorùbá belief system, still in the mortal world, because of the king's power to deal life or death, he is considered to be more respected. After the king are the chiefs, village heads (baálẹ), street heads (olórí àdúgbò), family heads (olórí ẹbí) and husbands (baálé). The people serving under the king are there to ensure there are checks and balances during the reign of the king because absolute power tends to corrupt absolutely. Therefore, the king must learn to manage his subjects in other to avoid anarchy in order to receive their unalloyed loyalty and obedience. When offended, a king must learn to either forgive or be diplomatic in penalizing the offender. This is what the Yorùbá refer to as fíf ẹjẹ sínú tu itọ funfun jáde (hiding blood and spitting out white saliva). Fadipe (1970) notes correctly and affirms that:

Anger is an emotion which is given very little overt expression. When a Yorùbá is angry, he often uses the language of diplomacy. He makes use of non-committal expressions and words whose meaning is reverse of what is meant. 'Keep the blood down in the system and spit out white saliva', is a proverb which is repeated as advice to a person to bide his own good time before thinking of resenting an injury (307).

Blood in the excerpt does not mean actual blood. Its use here is figurative. It simply symbolizes injury. When an individual is involved in an accident and he spits blood from his mouth, it may signify severe internal injury but when he spits out clear saliva, even if he is an inch from death, people may think he is in perfect shape. It is from this that the Yorùbá derive the act of pretending to be fine when they are irate. Odù Ọ̀kànrànsodẹ, an Ifá verse corroborates this:

Ilá so rúgúdú ọwo mi ọtún,

Ikàn so rùgùdù ọwọ mi òsì.

A dífá fún Olợin tó fẹjẹ sinú,

Tíi tu itọ funfun jáde.

Olợin ni ó fi àwọn ijòyè rẹ sinú,

O si ń wá ọnà àti șe aburú sí wọn.

Àpeẹre tí àwọn ijòyè rí lójú oorun,

Ló jẹ kí wọn lọ dáfá.

Wọ́n ní kí wọn rúbọ.

Wọ́n ní olórí wọn ń wá ọnà àti șe wọn níbi,

Ó kàn ń rệrìn-ín síwọn lásán ni.

Ėjẹ ló dì sinú tó ń tutọ́ funfun jáde.

Àwọn ijòyè rúbọ.

N jẹ mọ mọ jẹ n rijá aráyé, 
Oòpẹ mọ mọ jẹ n ríjà aráyé. ${ }^{9}$

Matured okra on my right palm,

Big egg-plant on my left palm.

Ifá divination was performed for Olọ́fin who hides blood inside,

And spits out white saliva.

Olọ́fin bears a grudge against his chiefs,

He is looking for ways to get back at them.

The signs that his chiefs saw in their dreams,

Made them go for divination.

They were told to make sacrifice.

They were told that their leader is plotting to harm them,

He was only feigning his approval of them.

He was absorbing blood and spitting out white saliva.

The chiefs made sacrifice.

May I not be made to suffer from the hands of evildoers,

Ọpẹ (Ifá) do not let me suffer from the hands of evildoers.

An analysis of this Ifá poem reveals Olọifin as a king that was not pleased with his chiefs. In lines 4-6 of the above Ifá poem, even though Olọ́fin was not pleased with his chiefs, he was diplomatic to disguise his true intent towards them. His chiefs were completely oblivious of his plans for them but for the visions they had in their dreams. After the chiefs had their visions, they went to have Ifá divination performed for them. Ộnúnmìà revealed Olộfin's plans to them. The chiefs performed sacrifice to avert the impending calamity from Olộfin. This shows that blood here symbolizes Oloọfin's bitterness that he shrouded from his chiefs and not the red liquid that flows in human's veins.

\section{Conclusion}

The primary focus of this paper was to undertake the literary interpretation of blood among the Yorùbá of Southwestern Nigeria as symbol as contained in selected Ifá divination poetry. The selected Ifá divination poetry analyzed in this study showed that blood, in the Yorùbá worldview, is a signifier of life, virginity, covenant, sacrifice, danger, identity and kinship. If studied closely, one can come to realize that these signifiers are closely connected and intertwined. In the Yorùbá belief system, any man who deflowers a lady, whether he likes it or not, has entered into a kind of covenant with the lady and such a covenant is sealed in the blood that was shed while the hymen was being

9 The data was collected from the oral interview conducted with Awo Oladiran Mathew at Ogbomoso in Oyo State, Nigeria on 10-29-2017. 
broken. This is because he is believed to have taken something from her that cannot be replaced and it is assumed that they are bonded for life. That is why when a bride is found to be virgo intacta (Fadipe (1970:83) by her husband on her wedding night, the bloodshed forms a covenant that surpasses any other kind of covenant they have made with words of mouth. The virginity of the bride as discussed earlier in this study is a pointer to her fertility. Therefore, when the bride gives birth to living children, the children become kinsmen to everybody the bride and groom are related to by blood and by marriage. The study also showed that it is possible for people to hide their true feelings towards others while planning to harm them. The Yorùbá refer to it as the act of hiding blood inside and spitting out white saliva. If the victims of this act are not discerning enough to act without delay to avert the enemy's plot, evil invariably results. The prompt action of Olofin's chiefs stressed the wisdom of making hay while the sun shines. The paper concludes that in the Yorùbá belief system, blood is, for the most part, symbolic and they view blood as sacred, revered and cultural. They also equate it with life.

I want to acknowledge Professor S.O. Ilesanmi, Washington. M. Wingate Professor of the Department for the Study of Religions, Wake Forest University for his input and edits in improving the quality of this paper.

\section{References}

Abimbola, W. (1975). Sixteen Great Poems of Ifá. Paris: UNESCO.

Adeniyi, V.O. (2015). "Portrayal of Indigenous Religions and Ifá Divination in Ola Rotimi's Gods are not to blame" David O. Ogungbile (ed.) African Indigenous Religious Traditions in Local and Global Contexts: Perspectives on Nigeria. (A Festschrift in Honour of Jacob K. Olupona. pp 175-185. Lagos: Malthouse Press Limited.

Ajibade, G.O. (2009). Finding Female Voice: A Socio-Cultural Appraisal of Yorùbá Nuptial Poetry. Cologne: Rudiger Koppe Verlag.

Akindipe, O. T. (2016) "Libation" In Toyin Falola and Akintunde Akinyemi (eds.) Encyclopedia of the Yorùbá. pp 197-198. Bloomington, Indiana: Indiana University Press.

Akindipe, O. T. (2016) "Spirit Possession" In Toyin Falola and Akintunde Akinyemi (eds.) Encyclopedia of the Yorùbá. pp 308-309. Bloomington, Indiana: Indiana University Press.

Apter, A. (2013). "The Blood of Mothers: Women, Money, and Markets in Yoruba-Atlantic Perspective." The Journal of African American History, Special Issue: Women, Slavery, and the Atlantic World (98)1: 72-98. 
Bally, C. and Sechehaye, A. (eds.) (1959). Saussure, Course in General Linguistics. New York: Philosophical Library.

Brown, K. (2018). "Blood on the Stones: Race, Epidemiology, and Theology". The Journal of Interreligious Studies. 23: 31-45.

Charon, J.M. (1998). Symbolic Interactionism: An Introduction, an Interpretation, an Integration. 6th ed. Englewood Cliffs, N.J.: Prentice-Hall.

Drewal, H. and Drewal, M. (1983). Gelede: Art and Female Power among the Yoruba. Indiana, Bloomington: Indiana University Press.

Drewal, H.J. and Mason, J. (1997). "Ogun and Body/Mind Potentially: Yoruba Scarification and Painting Traditions in Africa and Americas." Africa's Ogun, 332-352. Google Scholar.

Fadipe, N.A. (1970). The Sociology of the Yorùbá. Ibadan: Ibadan University Press.

Faleye, A.A. (2008). "Facial Marks (Ilà Kíkọ): A Dying Art among the Yorùba?” Humanities Review Journal, 8: 49-58.

Gbadegesin, E.O. (2016). "Symbols and Symbolism" In Toyin Falola and Akintunde Akinyemi (eds.) Encyclopedia of the Yorùbá. pp 315-316. Bloomington, Indiana: Indiana University Press.

https://www.britannica.com/science/blood-biochemistry retrieved on 26-03-2018

Long, C.H. (1986). Significations: Signs, Symbols, and Images in the Interpretation of Religion. Philadelphia: Fortress Press.

Makinde, M.A. (1988). African Philosophy, Culture, and Traditional Medicine. Ohio: Center for International Studies, Ohio University.

McCarthy, D. J. (1973). "Further Notes on the Symbolism of Blood and Sacrifice." Journal of Biblical Literature, 92(2): 205-210.

Mokgobi, M. G. (2014). "Understanding Traditional African Healing." African Journal for Physical Health Education, Recreation, and Dance, 20(Suppl 2): 24-34. Google Scholar.

Morton, A.L. (1979). Rethinking Symbolism. Cambridge: Cambridge University Press.

Nabofa, M.Y. (1985). “Blood Symbolism in African Religion.” Religious Studies, 21(3): 389-405.

Odejobi, C.O. (2013). "An Overview of Taboo and Superstition among the Yoruba of Southwest of Nigeria". Mediterranean Journal of Social Sciences, 4(2): 221-226.

Oguntola-Laguda, D. (2015). "Health, Healing and Restoring". In David O. Ogungbile (ed.) African Indigenous Religious Traditions in Local and Global Contexts: Perspectives on Nigeria. (A Festschrift in Honour of Jacob K. Olupona). pp 111-121. Lagos: Malthouse Press Limited. 
Olupona, J.K. (2011). City of 201 Gods: Ilé-Ifẹ in Time, Space and the Imagination. Berkeley: University of California Press.

Ricoeur, P. (1962). "The Hermeneutics of Symbols and Philosophical Reflection”, International Philosophical Quarterly 2(2): 191-218.

Ricoeur, P. (1974). The Conflict of Interpretations: Essays in Hermeneutics. Evanston: Northwestern University Press.

Taiwo, O. (2016). “Kí N’Ifá Wí? Philosophical Isssues in Ifá Divination”, In Jacob K. Olupona and Rowland O. Abiodun (eds.) Ifá Divination, Knowledge, Power and Performance. pp 100-116. Bloomington \& Indianapolis: Indiana University Press.

Washington, N. T. (2014). The Architects of Existence: Aje in Yoruba Cosmology, Ontology, and Orature. Oya's Tornado. Google Scholar.

Wescott, J. and Morton-Williams, P. (1962) "The Symbolism and Ritual Context of the Yoruba Laba Shango" The Journal of the Royal Anthropological Institute of Great Britain and Ireland, 92(1): 23-37.

White, L. A. (1950). “The Symbol: The Origin and Basis of Human Behavior". Philosophy of Science, 7(4): 451-463.

\section{Respondents}

Awo Dr. Fakayode Fayemi Fatunde at Baálẹ palace, Káà Ccompound, opposite Amuludun FM Radio Station, Alade town, Ibadan. Oyo State, Nigeria on 03-26-2018.

Iyalawo Ojo Ifabukola Ifalola at Obafemi Awolowo University Ile-Ife, Nigeria on $03-30-2017$

Awo Dr. Oladiran Mathew Ademola at Aníkan house, İrẹggbà-ọjà. Ogbomoso in Oyo State, Nigeria on 10-29-2017. 